\title{
A Study of the Development Direction Factors for Mass Customization of Clothing based on Digital Fashion System
}

\author{
Hosun Lim ${ }^{1)}$ and Hakyung $\mathrm{Cho}^{2) \dagger}$ \\ ${ }^{1)}$ Dept. of Clothing \& Textiles, Sookmyung Women's University; Seoul, Korea \\ ${ }^{2)}$ Dept. of R\&D, LUCIS Co., Ltd.; Seoul, Korea
}

\begin{abstract}
Due to the diversification of lifestyles and the rapid growth of Internet environments since the 1990s, mass customization has been recently accepted as an important trend in the area of clothing and all other areas. In response to mass customized clothing products, global clothing product brands are introducing systems for mass customization such as the application of digital fashion systems that introduced IT technologies such as CAD and 3D scanners. However, studies of planning factors for clothing products applied with digital fashion systems in the area of mass production of clothing products are insufficient. Therefore, this study was intended to analyze the lifestyles of 20-30s that are expected to have the highest demand for clothing applied with digital fashion systems and present basic planning factors according to lifestyles. Through the analysis, three groups that have one of fashion pursuing type, sensory information pursuing type, and practical function pursuing type lifestyles were derived. Based on this result, consumer demand for digital fashion systems and basic factors for product planning were analyzed to present basic planning factors for digital fashion system based customized clothing by lifestyle group. This study is meaningful in that it provided basic data for product planning through digital fashion systems by analyzing the awareness, preference, necessity, and planning factors of digital fashion systems through the analysis of lifestyle types.
\end{abstract}

Key words : digital fashion system, mass customized production, lifestyle, consumer demand, clothing product planning factor

\section{Introduction}

As consumers' tastes and lifestyles are diversified, interest in mass customized production systems that are consumer demand based product production methods is increasing instead of existing mass production systems(Lim \& Istook, 2011). As consumers' tastes are diversified, production systems that can quickly produce unique products in large quantities are required. With regard to changes in environments toward mass customized production, through a report titled 'The rise of mass customization and enterprises' response', Samsung Economic Research Institute stated that "as consumer markets were reorganized from public centered ones to individual customer oriented ones, mass customization has been established as a new business paradigm"(Samsung Economic Research Institute, 2003).

Reflecting this trend, consumers surpassed the status of consumers that buy produced products to require new production systems for small quantity batch production in the form of prosumers that make their opinions reflected in the stage of product planning.

†Corresponding author; Hakyung Cho

Tel. +82-2-368-3864, Fax. +82-2-368-3828

E-mail: instyle1010@naver.com
Production structures in the clothing industry have been also changed into small quantity batch production systems reflecting changes in demand characteristics in the market and thus technologies to activate mass customized production systems that reflect individual customers' demand characteristics have been actively developed(Chun \& Lim, 2003).

In addition, the utilization of the Internet that has been rapidly diffusing since the latter half of 1990s is preparing a new turning point for mass customization and mass customization in Internet based e-commerce environments has been recently accepted as an important trend in the area of clothing and all other areas(Eun \& Lee, 2006).

Following these environmental changes, recently, in the area of clothing too, digital fashion systems have been introduced as one of systems for mass customized production but basic studies of clothing planning factors are insufficient. Therefore, the present study was intended to analyze mass customization applied with digital fashion systems that are being established in the area of clothing, that is, to analyze demand from consumers as prosumers and basic factors for product planning according to lifestyles in order to present basic factors for planning of customized production type clothing products applied with digital fashion systems. 


\section{Literature Review}

\subsection{Mass customization system}

Mass customization is a compound word of the words mass production and customization and refers to a method of providing diverse high quality products(customization) while realizing low prices(massification) that can be achieved only in mass production systems(Eun, 2004).

In particular, the most important element of satisfying clothing fitness is understanding human bodies' characteristics and it can play some roles in creating stable markets in the clothing industry with mass customized production systems that satisfy consumers individual demands through by body types(Jang \& Chang, 2008).

Currently, terms that mean mass customized production applied in the clothing industry are divided into Easy Order, Size Order, System Order, and MTM(Made-to-Measure). Whereas easy order and MTM are systems in which patterns are made based on customers' body sizes and body types and styles or materials are selected according to customers' tastes so that clothes are custommade by individual, size order systems are operated centering on size fitness rather than design fitness functions. As these systems have been introduced, expectation of mass customized clothing has been heightened(Chun \& Lim, 2003).

This trend of mass customization meshed with the development of IT technologies such as Internet leading to recent increasing trends of Internet customizing services considering individuals' characteristics and tastes, of which the areas are being expanded thanks to the introduction of automatic systems for design, pattern making, and cutting through the utilization of technologies such as CAD. Burtons, Top Man, and Marks \& Spencer are materializing the potential of customized clothing with anthropometric scanners and computerized drafting and cutting technologies(Lee, 2002).

Mass customization of clothing products leads to positive effects; low costs and short cycle time by continuously focusing on gradual innovation and is expected to be a system with a high prospect for increasing market shares in terms of marketing functions as it will fill niche markets(Park, 2003).

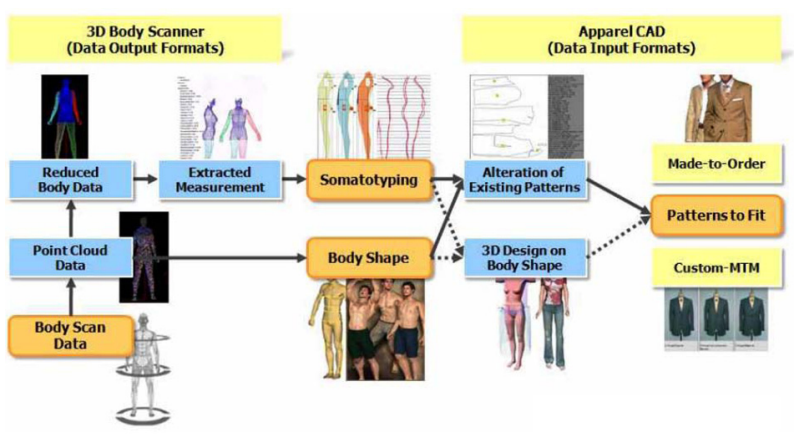

Fig. 1. Process of the clothing product based on costume MTM. KOFOTI (2008).

\subsection{Digital fashion system}

"Digital fashion systems" can be defined as PLM(Product Lifecycle Management) systems dedicated to customized mass production that control the entire cycle of the clothing fashion industry ranging from product planning to design-order-sales-productiondistribution to create new huge markets of customized mass production type MTM(Made-to-Measure) clothing products that are the next generation paradigm of the clothing fashion industry. That is, Digital fashion systems are mass customization systems that support small quantity batch production by supporting customized clothing products that enable consumers to express their unique individuality while maintaining the fashionableness of ready-made clothing products by fusing IT technologies and conventional textile and clothing industries' technologies.

As consumers' demand for customized products has been increasing, clothing products applied with these digital fashion systems have been attracting increasing attention throughout the world. MyVirtualModel(Canada)'s 3D digital human(avatar) service began in 2000 with clothing fashion related virtual experience and 3D shopping as business models and in the case of the USA, Levis and David's Bridal once implemented consumers' clothing size finding services using Intellifit scanners. In addition, in Europe, Bodymetrics(the UK, blue jeans), Corpus(Germany, made-to-order suit), Figleaves(the UK, lingerie/T-Bra), and Sam-

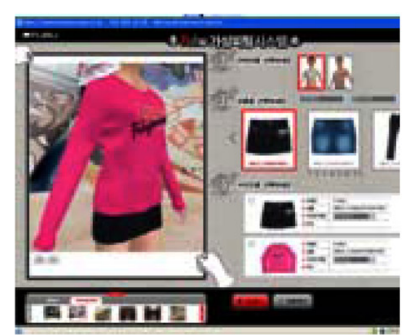

(a) Fubu

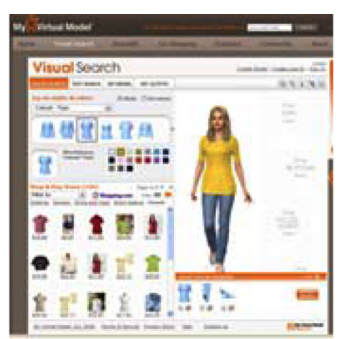

(b) MyVirtualModel

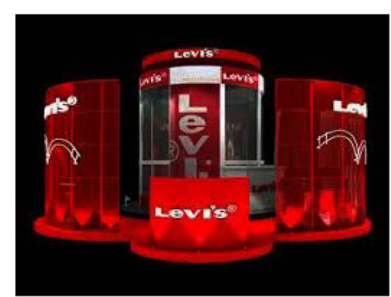

(c) Levis

Fig. 2. Example of the digital fashion system. 
son(France) provide customized clothing after measuring consumers' bodies using 3D scanners and MiAdidas provides customized shoes considering the shapes of consumers' feet. As such, digital fashion systems are being applied to diverse clothing products. Recently, in South Korea, ICT convergence fashion technologies including 3D virtual shopping using virtual reality are contributing to the creation of next generation textile and fashion industries such as unit technologies utilized by individual business units including 3D body scan, 3D computer graphics, 3D Simulation, DID, DTP and mass production technologies for customized order type products(Korea Federation of Textile Industries, 2008).

\section{Methods}

\subsection{Scope of the study}

The digital fashion systems presented in the present study were limited to those systems that produce customized clothing products reflecting newest fashion trends by implementing well-fitting clothes by customer using body type measurements by individual(including 3D human body scan) and optimized patterns. These systems refer to those systems in which customers can wear virtual clothing through 3D models in virtual spaces to select and purchase diverse styles, designs, and colors using cutting-edge technologies.

\subsection{Questionnaire composition}

The purpose of the present study was to present basic factors for product planning through the analysis of the acceptance and images of customized clothing products applied with digital fashion systems according to lifestyles. For the lifestyle scale used in the present study, considering the fact that customized clothing products applied with digital fashion systems are an IT convergence technology, fashion lifestyle and digital lifestyle questions that are expected to have the largest effects were composed. The fashion lifestyle questions were derived from previous studies(Eun, 2004; Lee, 2002; Park, 2002) and composed to fit the present study through revisions and supplementation and the digital lifestyle questions were composed by considering recent lifestyle related Internet sites, etc., extracting questions from previous studies(Choi, 2002; Lee, 2004), and revising and supplementing the questions to fit the content of the present study. In addition, to analyze consumer needs for customized clothing products applied with digital fashion systems according to lifestyles, attempts were made to analyze the images of clothing products, preferred brand images, and major factors considered during purchases through the Internet. The questionnaire questions used in the present study include 17 fashion lifestyle questions and 19 digital lifestyle questions composed of 5point Likert scales. In addition, the questions comprised 13 questions regarding items related to the analysis of consumers' basic demand, 38 questions for image assessment and comparison, seven

Table 1. Fashion lifestyle factor analysis

\begin{tabular}{|c|c|c|c|c|c|}
\hline Factor & Item & $\begin{array}{l}\text { Factor } \\
\text { loading }\end{array}$ & $\begin{array}{l}\text { Eigen } \\
\text { value }\end{array}$ & $\begin{array}{l}\text { Explanatory } \\
\text { variable(\%) }\end{array}$ & $\begin{array}{l}\text { Cumulative } \\
\text { variance }(\%)\end{array}$ \\
\hline $\begin{array}{c}\text { Fashion } \\
\text { pursuing type }\end{array}$ & $\begin{array}{l}\text { - Surrounding people seem to think that I am a good adviser for clothing fashion. } \\
\text { - Even if a little outstanding, I would like to show clothes that will lead new fashion } \\
\text { to others. } \\
\text { - I do not roughly read fashion related magazines and make effort to have my } \\
\text { clothes keep up with newest fashion. } \\
\text { - I affect the clothing styles bought by surrounding people. } \\
\text { - When I pluck up my courage and wear new style clothes earlier than others, the } \\
\text { clothes would become trendy thereafter. } \\
\text { - I am confident in my ability to perceive fashion trends. } \\
\text { - I mainly wear those styles of clothing that are in fashion. } \\
\text { - I have told about clothing styles that have been in fashion recently to somebody. }\end{array}$ & $\begin{array}{l}.746 \\
.768 \\
.803 \\
.738 \\
.783 \\
.745 \\
.780 \\
.746\end{array}$ & 8.14 & 40.704 & 40.704 \\
\hline $\begin{array}{c}\text { Sensation } \\
\text { pursuing type }\end{array}$ & $\begin{array}{l}\text { - If I find a new design that fits my image, I will buy it regardless of fashion. } \\
\text { - I am very sensitive about whether the colors of clothes and socks, etc. harmonize } \\
\text { with each other. } \\
\text { - I would like to change my image sometimes with daring dress. } \\
\text { - I buy clothes that I like regardless of fashion. } \\
\text { - I frequently wonder what designs would harmonize with my face and body type. }\end{array}$ & $\begin{array}{l}.624 \\
.622 \\
.632\end{array}$ & 1.71 & 8.569 & 49.273 \\
\hline $\begin{array}{l}\text { Practicali-ty } \\
\text { pursuing type }\end{array}$ & $\begin{array}{l}\text { - When choosing my clothes, I think functionality and prices first rather than colors } \\
\text { or designs. } \\
\text { - I trust products of widely known brands more than other products. } \\
\text { - Even if I like some clothes, I do not buy them if managing them is difficult. } \\
\text { - I mostly buy simple and classic designs that are not related to fashion. }\end{array}$ & $\begin{array}{l}.486 \\
.532 \\
.542\end{array}$ & 1.38 & 6.927 & 56.200 \\
\hline
\end{tabular}


questions for basic planning of clothing applied with digital fashion systems, and finally, five questions about demographic characteristics.

\subsection{Analysis methods}

For the analysis of planning of customized clothing products applied with digital fashion systems, a survey was conducted from December 1, 2010 to January 15, 2011. A total of 400 copies of questionnaires were distributed to mainly those in their $20 \sim 30 \mathrm{~s}$ expected to demand customized clothing products applied with MTM based digital fashion systems and among the 400 copies of questionnaires, 364 significant copies excluding 36 copies that were statistically meaningless were utilized in the analysis.

Frequency analysis, factor analysis, cluster analysis, and cross analysis were utilized for statistical analyses using SPSS 18.0 and Excel programs and ANOVAs were conducted to analyze differences between groups according to lifestyles.

\section{Results}

\subsection{Analysis of the types of consumer lifestyles}

In the present study, to present basic planning plans for digital fashion system based customized clothing products according to lifestyles, questions about fashion lifestyles and digital lifestyles that are considered to have the largest effects on clothing applied with digital fashion systems were composed, factor analyses were conducted for the questions, and the results were presented. To review the reliability and validity of the data, factor analyses were conducted using the Varimax rotation method and the principal component analysis method and factors were extracted based on eigen values exceeding 1.0. As a result, fashion lifestyles were divided into fashion pursuing types, sensation pursuing types, and practicality pursuing types and digital lifestyles were divided into information pursuing types, early adopter types, and function pursuing types(Table 1, 2).

Based on the results of the above factor analysis, the respondents' clusters according to their lifestyles were analyzed in order to analyze planning elements for customized clothing products applied with digital fashion systems according to consumers' lifestyle.

Cluster analyses were conducted based on factor scores of individual factors to divide customers into three clusters and to divide the clusters by type, the arithmetic mean values of the factor scores of customers in individual clusters were compared with each other to group the customers(Table 3), and characteristics by group were presented(Table 4).

Table 2. Digital lifestyle factor analysis

\begin{tabular}{|c|c|c|c|c|c|}
\hline Factor & Item & $\begin{array}{l}\text { Factor } \\
\text { loading }\end{array}$ & $\begin{array}{l}\text { Eigen } \\
\text { value }\end{array}$ & $\begin{array}{l}\text { Explanatory } \\
\text { variable(\%) }\end{array}$ & $\begin{array}{l}\text { Cumulative } \\
\text { variance }(\%)\end{array}$ \\
\hline $\begin{array}{l}\text { Information } \\
\text { pursuing } \\
\text { type }\end{array}$ & $\begin{array}{l}\text { - When I have bought a new device, I examine and study the manual } \\
\text { and data related to the device. } \\
\text { - I enjoy leaving my opinions or writings through the Internet. } \\
\text { - I enjoy playing online games. } \\
\text { - I frequently use Internet functions of mobile phones/ PDA. } \\
\text { - I frequently use messengers such as Nate On. } \\
\text { - I use the Internet for learning. } \\
\text { - I obtain information through the Internet instead of paper media. } \\
\text { - I check my e-mail almost every day. } \\
\text { - I frequently watch DMB through PMP and mobile phones. }\end{array}$ & $\begin{array}{l}.823 \\
.622 \\
.634 \\
.642 \\
.584 \\
.623 \\
.607 \\
.582 \\
.488\end{array}$ & 6.32 & 33.271 & 33.271 \\
\hline $\begin{array}{c}\text { Early } \\
\text { adopter } \\
\text { type }\end{array}$ & $\begin{array}{l}\text { - I am much interested in mobile devices such as PMP and MP3. } \\
\text { - I am much interested in new devices. } \\
\text { - When one of my friends around me has bought a new device (mobile } \\
\text { phone, PMP, etc.), I become to be much interested in it. } \\
\text { - I frequently replace my mobile phone. } \\
\text { - I am an early adopter (Those who buy and use newest devices } \\
\text { equipped with high tech technologies earlier than anyone else). }\end{array}$ & $\begin{array}{l}.761 \\
.744 \\
.725 \\
.656 \\
.604\end{array}$ & 1.93 & 10.195 & 43.466 \\
\hline $\begin{array}{l}\text { Function } \\
\text { pursuing } \\
\text { type }\end{array}$ & $\begin{array}{l}\text { - I consider functions first rather than designs. } \\
\text { - I think practicality should be regarded to be the most important for } \\
\text { electronic products. } \\
\text { - I frequently buy products through home shopping or Internet } \\
\text { shopping. } \\
\text { - I use the Internet when I send money. } \\
\text { - I collect shopping information through the Internet. }\end{array}$ & $\begin{array}{l}.654 \\
.624 \\
.528 \\
.506 \\
.502\end{array}$ & 1.33 & 7.025 & 50.491 \\
\hline
\end{tabular}


Table 3. Results of cluster analysis according to lifestyles

\begin{tabular}{|c|c|c|c|c|}
\hline & & Factor1 & Factor 2 & Factor 3 \\
\hline \multirow{3}{*}{ Fashion Lifestyles } & Fashion pursuing type & .31710 & .10728 & .95263 \\
\hline & Sensation information pursuing type & -.63277 & .91688 & .15691 \\
\hline & Practical function pursuing type & .96671 & .54358 & -.77858 \\
\hline \multirow{3}{*}{ Digital Lifestyles } & Fashion pursuing type & -1.10156 & .61254 & 1.13751 \\
\hline & Sensation information pursuing type & -1.22618 & 2.13434 & -1.39115 \\
\hline & Practical function pursuing type & 1.87558 & .60404 & -.65485 \\
\hline
\end{tabular}

Table 4. Characteristics of groups

\begin{tabular}{ll}
\hline \multicolumn{1}{c}{ Group name } & Lifestyle characteristics \\
$\begin{array}{ll}\text { Fashion pursuing type } & \text { A group of those that have individual fashion styles and are much interested in the latest fashion and digital devices } \\
\begin{array}{l}\text { Sensation information } \\
\text { pursuing type }\end{array} & \begin{array}{l}\text { A group of those that regard fashion senses and harmony important and prefer obtaining information through digital } \\
\text { devices and Internet }\end{array} \\
\begin{array}{l}\text { Practical function pursuing A group of those that regard functions and practicality important for fashion and pursue the utilization of functions through } \\
\text { type }\end{array} & \text { mobile as their digital life style }\end{array}$
\end{tabular}

To identify characteristics by lifestyle, the respondents were demographically divided and differences between lifestyle groups were analyzed using $\chi^{2}$ tests. According to the results, the lifestyle groups showed significant differences in the variables; age, academic background, and occupation as follows but did not show any significant difference in the variables; gender and income(Table 5). Among the respondents in the fashion pursuing type group, at least $60 \%$ were aged $20 \sim 30$ years and more of them were university undergraduates compared to other groups. Among the respondents in the information pursuing type group, the numbers of those aged 20 25 years, or $30 \sim 35$ years were the largest and the number of those that were working as salaried employees after graduating from university was the largest. Among the respondents in the practical function pursuing type group, the number of those aged 35 40 was the largest and the number of those that were working as salaried employees after graduating from university was the largest.

\subsection{Analysis of basic fashion pursuing factors by group}

1) Analysis of preferred brands by lifestyle

According to the results of analysis of fashion images pursued by lifestyle, the practical function pursuing type group showed a tendency to prefer natural casual image close to classic, the sensation information pursuing type group preferred classic, luxury, and elegant images, and the fashion pursuing type group preferred contemporary fashion images with celebrity trends.

When the tendencies to prefer casual clothing expected to be the initial market group of digital fashion system based customized clothing were analyzed, the practical function pursuing type group was shown to prefer easy casuals such as TBJ, Giordano, and NII, the sensation information pursuing type group shows a pattern of preferring value casuals which are a sensory casual line such as Mind Bridge, Norton Homme, EmPolham, and Jack \& Jill, and the fashion pursuing type group showed a pattern of pursuing expensive stylish character casuals and preferring trend casuals with firm brand concepts such as Andew, Kai-Aakmann, and Chris Christy.

2) Factors considered when clothes are purchased according to lifestyles

Factors considered the most important when clothes are considered by lifestyle were analyzed according to lifestyles with a view to reflecting the results on the planning of clothing products applied with digital fashion systems.

In the case of casual clothing, the groups showed differences in materials, designs, and fashion. The practical function pursuing type group assessed the importance of materials to be higher compared to other groups and the fashion pursuing type group considered the factors, design and fashion more important compared to other groups.

In the case of sports wear, the fashion pursuing type group assessed the factor fashion to be a major factor but other items did not show any difference among the groups.

In the case of underwear, the fashion pursuing type group considered fashion and the practical function pursuing type group assessed the factor price adequacy to be a major factor to be considered.

Suits were identified as showing differences among the groups in the largest number of factors compared to other clothing types. The practical function pursuing type group considered the factors; colors, activity, price adequacy, and brand celebrity more important 
Table 5. Demographic characteristics

\begin{tabular}{|c|c|c|c|c|c|c|c|c|}
\hline & & \multicolumn{2}{|c|}{$\begin{array}{c}\text { Fashion pursuing } \\
\text { type }(\mathrm{N})\end{array}$} & \multicolumn{2}{|c|}{$\begin{array}{l}\text { Sensation information } \\
\text { pursuing type }(\mathrm{N})\end{array}$} & \multicolumn{2}{|c|}{$\begin{array}{l}\text { Practical function } \\
\text { pursuing type }(\mathrm{N})\end{array}$} & \multirow[t]{2}{*}{$\chi^{2}$} \\
\hline \multirow{4}{*}{ Age } & $20 \sim 25$ years & 33 & $34.4 \%$ & 36 & $28.3 \%$ & 29 & $20.6 \%$ & \\
\hline & $25 \sim 30$ years & 29 & $30.2 \%$ & 29 & $22.8 \%$ & 18 & $12.8 \%$ & \multirow{4}{*}{$53.21 * *$} \\
\hline & $30 \sim 35$ years & 16 & $16.7 \%$ & 34 & $26.8 \%$ & 30 & $21.3 \%$ & \\
\hline & $35 \sim 40$ years & 18 & $18.8 \%$ & 28 & $22.0 \%$ & 64 & $45.4 \%$ & \\
\hline & Total & $96(26.4 \%)$ & $100 \%$ & $127(34.9 \%)$ & $100 \%$ & $141(38.7 \%)$ & $100 \%$ & \\
\hline \multirow{2}{*}{ Gender } & Male & 25 & $26.0 \%$ & 40 & $31.5 \%$ & 40 & $28.4 \%$ & \multirow{3}{*}{6.57} \\
\hline & Female & 71 & $74.0 \%$ & 87 & $68.5 \%$ & 101 & $71.6 \%$ & \\
\hline & Total & $96(26.4 \%)$ & $100 \%$ & $127(34.9 \%)$ & $100 \%$ & $141(38.7 \%)$ & $100 \%$ & \\
\hline \multirow{4}{*}{$\begin{array}{l}\text { Academic } \\
\text { background }\end{array}$} & High school graduation & 25 & $26.0 \%$ & 8 & $6.3 \%$ & 18 & $12.8 \%$ & \multirow{5}{*}{$22.41^{* *}$} \\
\hline & University graduation & 52 & $54.2 \%$ & 84 & $66.1 \%$ & 82 & $58.2 \%$ & \\
\hline & Graduate school graduation & 17 & $17.7 \%$ & 34 & $26.8 \%$ & 40 & $28.4 \%$ & \\
\hline & Other & 2 & $2.1 \%$ & 1 & $0.8 \%$ & 1 & $0.7 \%$ & \\
\hline & Total & $96(26.4 \%)$ & $100 \%$ & $127(34.9 \%)$ & $100 \%$ & $141(38.7 \%)$ & $100 \%$ & \\
\hline \multirow{6}{*}{ Occupation } & Salaried employee & 17 & $17.7 \%$ & 36 & $28.3 \%$ & 65 & $46.1 \%$ & \multirow{7}{*}{$34.18 * *$} \\
\hline & Self-employed & 7 & $7.3 \%$ & 30 & $23.6 \%$ & 24 & $17.0 \%$ & \\
\hline & Profession & 7 & $7.3 \%$ & 28 & $22.0 \%$ & 21 & $14.9 \%$ & \\
\hline & Full-time homemaker & 2 & $2.1 \%$ & 5 & $3.9 \%$ & 11 & $7.8 \%$ & \\
\hline & Student & 60 & $62.5 \%$ & 24 & $18.9 \%$ & 14 & $9.9 \%$ & \\
\hline & Other & 3 & $3.1 \%$ & 4 & $3.1 \%$ & 6 & $4.3 \%$ & \\
\hline & Total & $96(26.4 \%)$ & $100 \%$ & $127(34.9 \%)$ & $100 \%$ & $141(38.7 \%)$ & $100 \%$ & \\
\hline \multirow{5}{*}{ Income } & 1million won or less & 0 & $0.0 \%$ & 1 & $0.8 \%$ & 0 & $0.0 \%$ & \multirow{6}{*}{12.43} \\
\hline & $1 \sim 3$ million won & 31 & $32.3 \%$ & 27 & $21.3 \%$ & 46 & $32.6 \%$ & \\
\hline & $3 \sim 5$ million won & 42 & $43.8 \%$ & 27 & $21.3 \%$ & 65 & $46.1 \%$ & \\
\hline & $5 \sim 10$ million won & 18 & $18.8 \%$ & 65 & $51.2 \%$ & 28 & $19.9 \%$ & \\
\hline & 10 million won or more & 5 & $5.2 \%$ & 7 & $5.5 \%$ & 2 & $1.4 \%$ & \\
\hline & Total & $96(26.4 \%)$ & $100 \%$ & $127(34.9 \%)$ & $100 \%$ & $141(38.7 \%)$ & $100 \%$ & \\
\hline
\end{tabular}

compared to other group(Table 6).

Factors considered when clothes are purchased were analyzed by clothing types and lifestyle and according to the results, the sensation information pursuing type group assessed colors, designs, easiness of management, activity, wearability, harmony with existing clothes, and sewn states to be major factors to be considered in the case of clothing; materials, easiness of management, activity, wearability, durability, and functionality to be major factors to be considered in the case of sports wear; and materials, easiness of management, activity, wearability, durability, functionality, and sewn states to be major factors to be considered in the case of underwear. In the case of suits, this group assessed colors, materials, designs, wearability, harmony with existing clothes , and sewn states to be major factors to be considered(Fig. 3).

The fashion pursuing type group was shown to assess all items equally to be factors to be considered with higher importance com- pared other groups. In the case of casual wear, this group perceived colors, designs, fashion, easiness of management, activity, wearability, harmony with existing clothes, sewn states as major factors to be considered while assessing all items except for fashion, brand celebrity, and sewn states to be major factors to be considered in the case of sports wear. In the case of underwear, this group was shown to consider materials, easiness of management, activity, wearability, durability, functionality, and sewn states as major factor and in the case of suits, this group was shown to perceive colors, materials, designs, wearability, brand celebrity, harmony with existing clothes, and sewn states as major factors to be considered(Fig. 4).

The practical function pursuing type group was shown to assess colors, materials, designs, easiness of management, activity, wearability, price adequacy, harmony with existing clothes, and sewn state to be major factors to be considered in the case of casual wear, and materials, designs, easiness of management, activity, weara- 
Table 6. Major factors considered when clothes are purchased by group

\begin{tabular}{|c|c|c|c|c|c|}
\hline \multirow[t]{2}{*}{ Item } & \multirow[t]{2}{*}{ Factors } & $\begin{array}{c}\text { Sensation information } \\
\text { pursuing type }\end{array}$ & Fashion pursuing type & $\begin{array}{l}\text { Practical function } \\
\text { pursuing type }\end{array}$ & \multirow[t]{2}{*}{ F-value } \\
\hline & & Mean \pm SD & Mean \pm SD & Mean \pm SD & \\
\hline \multirow{3}{*}{ Casual } & Materials & $\begin{array}{l}3.78 \pm 0.75 \\
\text { (B) }\end{array}$ & $\begin{array}{c}3.63 \pm 0.66 \\
(\mathrm{AB})\end{array}$ & $\begin{array}{l}4.06 \pm 0.75 \\
\text { (A) }\end{array}$ & $3.488^{*}$ \\
\hline & Designs & $\begin{array}{c}4.15 \pm 0.63 \\
\text { (A) }\end{array}$ & $\begin{array}{c}4.60 \pm 0.49 \\
\text { (B) }\end{array}$ & $\begin{array}{c}4.21 \pm 0.79 \\
\text { (A) }\end{array}$ & $4.472 * *$ \\
\hline & Fashion & $\begin{array}{l}3.35 \pm 0.90 \\
\text { (A) }\end{array}$ & $\begin{array}{c}4.07 \pm 0.69 \\
\text { (B) }\end{array}$ & $\begin{array}{c}3.83 \pm 0.83 \\
\text { (B) }\end{array}$ & $7.715^{* * *}$ \\
\hline Sportswear & Fashion & $\begin{array}{c}3.11 \pm 0.70 \\
\text { (A) }\end{array}$ & $\begin{array}{l}3.60 \pm 0.81 \\
\text { (B) }\end{array}$ & $\begin{array}{c}3.35 \pm 0.97 \\
(\mathrm{AB})\end{array}$ & $3.115^{*}$ \\
\hline \multirow{2}{*}{ Underwear } & Fashion & $\begin{array}{c}2.57 \pm 0.93 \\
\text { (A) }\end{array}$ & $\begin{array}{l}3.13 \pm 0.97 \\
(\mathrm{AB})\end{array}$ & $\begin{array}{c}2.60 \pm 1.04 \\
\text { (A) }\end{array}$ & $3.515^{*}$ \\
\hline & Price adequacy & $\begin{array}{c}3.87 \pm 0.93 \\
(\mathrm{AB})\end{array}$ & $\begin{array}{c}3.57 \pm 0.93 \\
\text { (A) }\end{array}$ & $\begin{array}{c}4.13 \pm 0.91 \\
\text { (B) }\end{array}$ & $3.381 *$ \\
\hline \multirow{4}{*}{ Suits } & Color & $\begin{array}{l}4.04 \pm 0.59 \\
(\mathrm{AB})\end{array}$ & $\begin{array}{l}4.10 \pm 0.60 \\
(\mathrm{AB})\end{array}$ & $\begin{array}{c}4.35 \pm 0.78 \\
\text { (A) }\end{array}$ & $2.726^{*}$ \\
\hline & Activity & $\begin{array}{l}3.72 \pm 0.98 \\
(\mathrm{AB})\end{array}$ & $\begin{array}{c}3.53 \pm 0.86 \\
\text { (A) }\end{array}$ & $\begin{array}{c}4.00 \pm .077 \\
\text { (B) }\end{array}$ & $2.164 *$ \\
\hline & Price adequacy & $\begin{array}{c}3.89 \pm 0.66 \\
\text { (A) }\end{array}$ & $\begin{array}{c}3.80 \pm 0.88 \\
\text { (A) }\end{array}$ & $\begin{array}{l}4.46 \pm 0.71 \\
\text { (B) }\end{array}$ & $10.732 * * *$ \\
\hline & Brand celebrity & $\begin{array}{c}3.67 \pm 0.70 \\
\text { (A) }\end{array}$ & $\begin{array}{c}4.03 \pm 0.66 \\
\text { (B) }\end{array}$ & $\begin{array}{l}4.00 \pm 0.82 \\
(\mathrm{AB})\end{array}$ & $3.016^{*}$ \\
\hline
\end{tabular}

A, B : categorization of the groups for the significant differences between groups

bility, durability, functionality, price adequacy, and sewn states to be major factors to be considered in the case of sports wear. In the case of underwear, this group assessed materials, easiness of management, activity, wearability, durability, functionality, price adequacy, and sewn states to be major factors to be considered and in the case of suits, this group assessed colors, materials, designs, easiness of management, activity, wearability, durability, price adequacy, brand celebrity, harmony with existing clothes, and sewn states to be major factors to be considered(Fig. 5).

The factors to be considered when clothes are purchased were

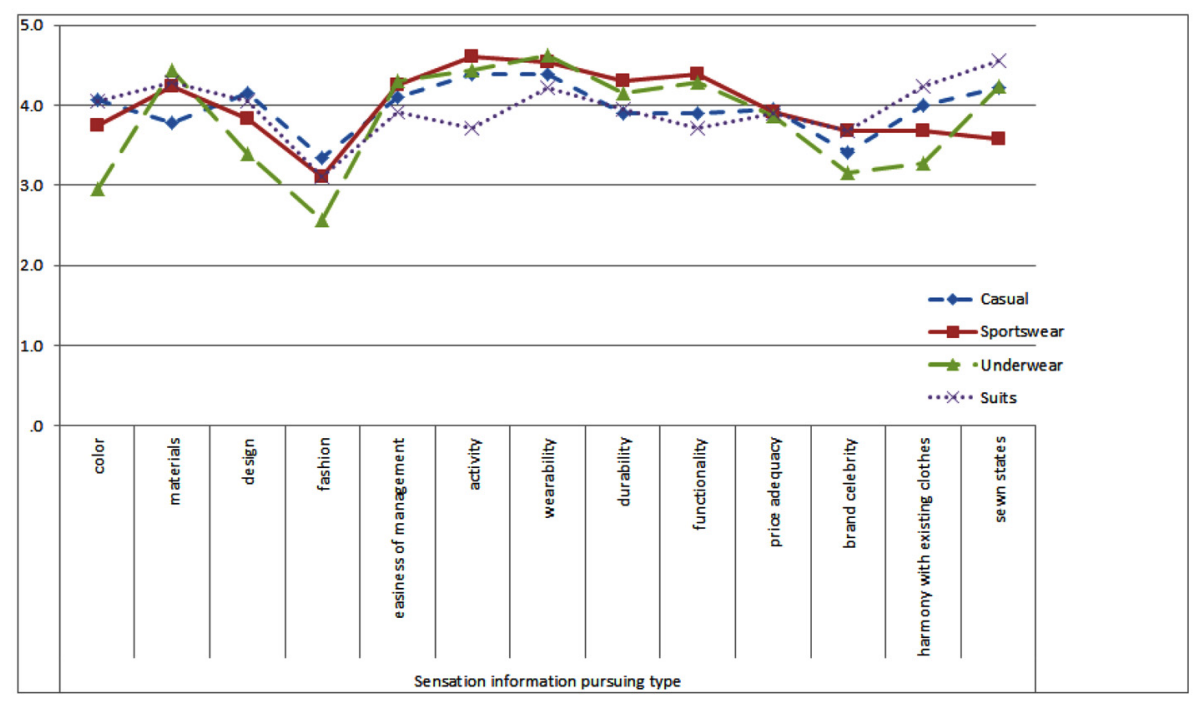

Fig. 3. Analysis of factors considered when clothes are purchased by the information pursuing type group. 


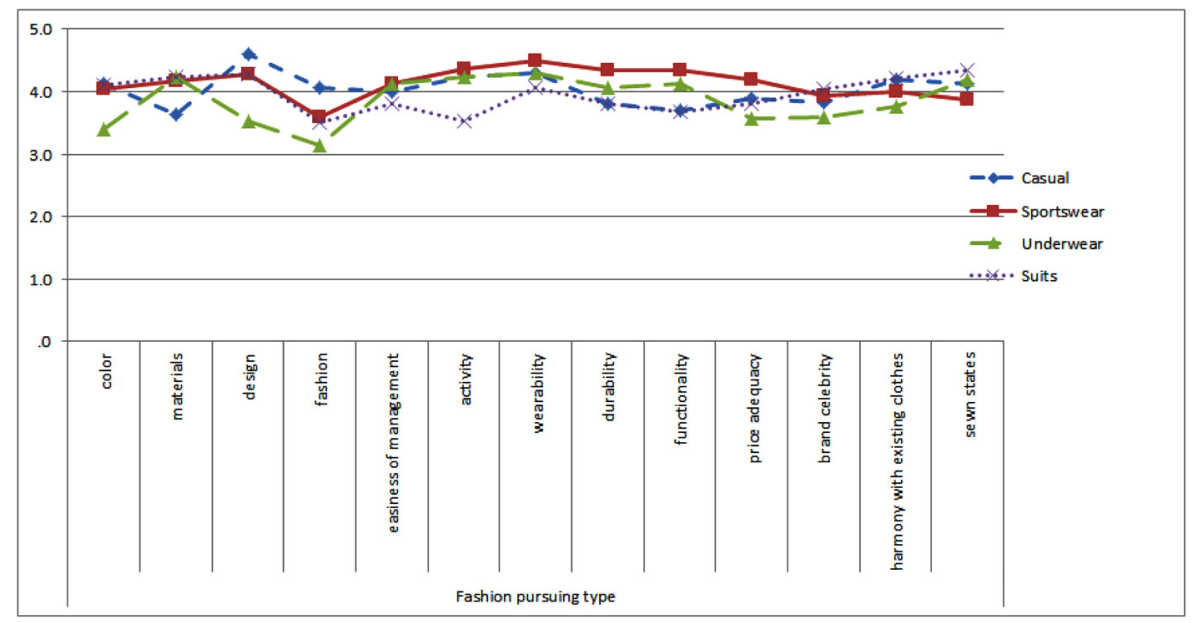

Fig. 4. Analysis of factors considered when clothes are purchased by the fashion pursuing type group.

integrated and analyzed and detailed factors to be considered when clothes are purchased by clothing type were compared with each other. Then, factors that were considered the most important when each of suits, casual, sports wear, and underwear were purchased respectively were cross-analyzed. The results did not show any significant difference but the respondents showed a tendency to buy clothes less affected by fashion when they were buying suits compared to when they were buying casual wear. In addition, the respondents were shown to regard materials and brand celebrity when they were buying casual wear compared to when they were buying suits and they showed a tendency to regard easiness of management and washing and prices more important compared to when they were buying other types of clothing. Finally, when they were buying underwear, they regarded the factors; colors, fashion, brand celebrity, and harmony with existing clothes less important and the factor; materials more important compared to when they were buying other types of clothes. This analysis was intended to present matters that must be considered when each type of clothing products applied with digital fashion systems is planned as approaches by clothing type.

\subsection{Awareness and acceptance levels of clothing} products applied with digital fashion systems by group

The awareness, necessity, and acceptance of clothing products applied with digital fashion systems by lifestyle were analyzed and according to the results, the fashion pursuing type showed the highest awareness of clothing products applied with digital fashion systems among the three group while showing the lowest necessity

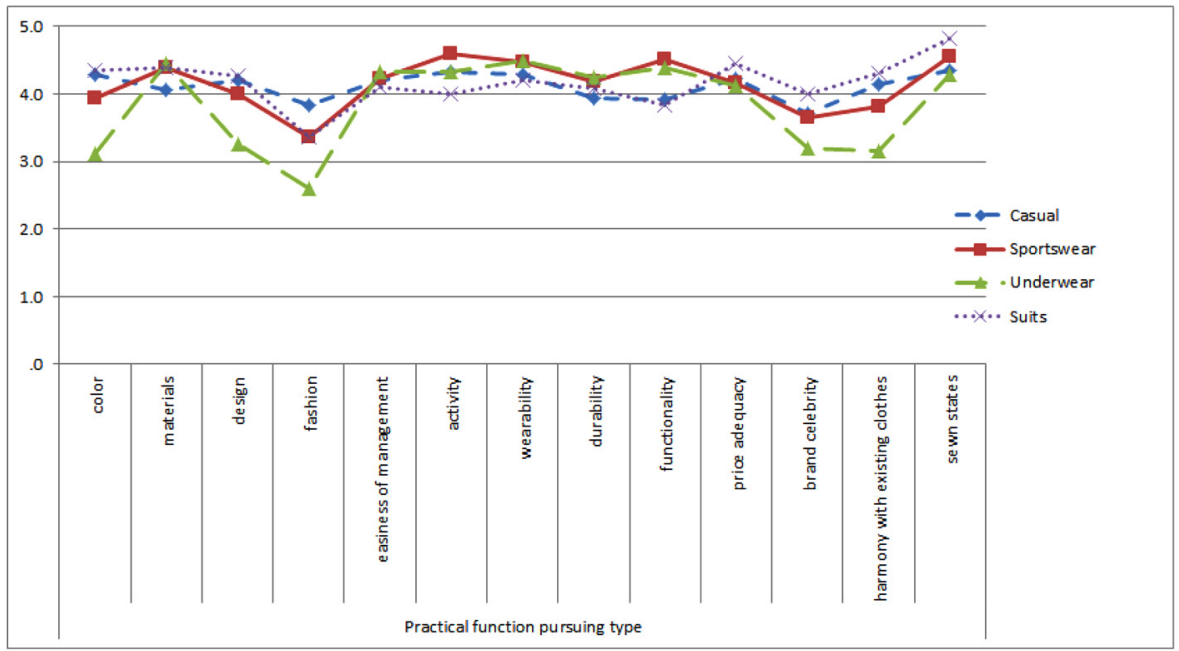

Fig. 5. Analysis of factors considered when clothes are purchased by the practical function pursuing type group. 
Table 7. Results of assessment of the awareness and acceptance levels of customized clothing products applied with digital systems

\begin{tabular}{|c|c|c|c|c|}
\hline \multirow{2}{*}{ Item } & Sensation information pursuing type & Fashion pursuing type & Practical function pursuing type & \multirow{2}{*}{ F-value } \\
\hline & Mean \pm SD & Mean \pm SD & Mean \pm SD & \\
\hline Awareness & $\begin{array}{c}3.47 \pm 1.08 \\
(\mathrm{AB})\end{array}$ & $\begin{array}{c}3.65 \pm 0.95 \\
(\mathrm{AB})\end{array}$ & $\begin{array}{c}3.26 \pm 0.93 \\
\text { (B) }\end{array}$ & $4.856^{* *}$ \\
\hline Necessity & $\begin{array}{c}3.30 \pm 1.17 \\
\text { (A) }\end{array}$ & $\begin{array}{c}2.70 \pm 1.29 \\
\text { (B) }\end{array}$ & $\begin{array}{c}2.83 \pm 1.27 \\
\text { (B) }\end{array}$ & $7.711^{* * *}$ \\
\hline Acceptance & $3.69 \pm 0.77$ & $3.54 \pm 0.92$ & $3.69 \pm 0.76$ & 1.323 \\
\hline
\end{tabular}

$* * p<.01, * * * p<.001$

A, B : categorization of the groups for the significant differences between groups

and acceptance levels(Table 7).

The sensation information pursuing type showed a lower awareness level compared to the fashion pursuing type group while showing the highest scores among the three groups in terms of necessity and acceptance thereby indicating the highest intention to buy clothing products applied with digital fashion systems.

\subsection{Analysis of the images of clothing products applied} with digital fashion systems

1) Analysis of the images of clothing products applied with digital fashion systems

The images of clothing products applied with digital fashion systems in the lifestyle groups were analyzed and the results indicated that the groups showed significant differences in items; fancy, fashionable, moderate, and unique. The fashion pursuing type group was shown to assess the clothing products as having fancy, fashionable, and unique images while being moderate compared to their preferred brands. On the other hand, the practical function pursuing type was identified as perceiving customized clothing applied with digital fashion systems as not being moderate but being unique(Table 8 ).

2) Comparison of preferred brand images by lifestyle

Preferred brand images were compared among the lifestyle groups and the results indicated that significant differences were shown among the groups in items; luxurious, fancy, fashionable,

Table 8. Assessment of digital fashion system image factors according to lifestyles

\begin{tabular}{|c|c|c|c|c|}
\hline \multirow{2}{*}{ Item } & Sensation information pursuing type & Fashion pursuing type & Practical function pursuing type & \multirow{2}{*}{ F-value } \\
\hline & Mean \pm SD & Mean \pm SD & Mean \pm SD & \\
\hline luxurious & $4.10 \pm 0.77$ & $4.29 \pm 0.69$ & $3.98 \pm 0.75$ & 1.632 \\
\hline fancy & $\begin{array}{c}3.35 \pm 0.87 \\
\text { (A) }\end{array}$ & $\begin{array}{c}3.65 \pm 0.83 \\
\text { (A) }\end{array}$ & $\begin{array}{l}2.79 \pm 1.01 \\
\text { (B) }\end{array}$ & $8.946^{* * *}$ \\
\hline feminine & $3.42 \pm 0.89$ & $3.42 \pm 0.92$ & $3.73 \pm 1.05$ & 1.636 \\
\hline fashionable & $\begin{array}{c}3.10 \pm 0.67 \\
\text { (A) }\end{array}$ & $\begin{array}{c}3.23 \pm 1.05 \\
\text { (A) }\end{array}$ & $\begin{array}{c}2.73 \pm 0.97 \\
\text { (B) }\end{array}$ & $7.919 * *$ \\
\hline mature & $3.00 \pm 0.79$ & $3.03 \pm 0.87$ & $2.94 \pm 0.89$ & 0.126 \\
\hline moderate & $\begin{array}{c}3.16 \pm 0.87 \\
(\mathrm{AB})\end{array}$ & $\begin{array}{c}3.69 \pm 0.84 \\
\text { (A) }\end{array}$ & $\begin{array}{c}2.97 \pm 0.83 \\
\text { (B) }\end{array}$ & $7.325^{* *}$ \\
\hline casual & $3.54 \pm 0.77$ & $3.51 \pm 0.82$ & $3.53 \pm 0.84$ & 0.539 \\
\hline plain & $3.14 \pm 0.98$ & $3.20 \pm 0.88$ & $2.90 \pm 0.97$ & 0.575 \\
\hline simple & $3.50 \pm 0.94$ & $3.03 \pm 0.91$ & $3.77 \pm 1.08$ & 2.350 \\
\hline masculine & $2.92 \pm 1.02$ & $2.48 \pm 0.96$ & $2.69 \pm 1.05$ & 1.713 \\
\hline classic & $3.44 \pm 0.87$ & $3.29 \pm 0.82$ & $3.51 \pm 1.08$ & 0.513 \\
\hline cute & $2.96 \pm 0.98$ & $3.48 \pm 1.06$ & $3.20 \pm 0.95$ & 2.654 \\
\hline unique & $\begin{array}{c}3.11 \pm 1.07 \\
\text { (A) }\end{array}$ & $\begin{array}{c}2.58 \pm 0.99 \\
\text { (B) }\end{array}$ & $\begin{array}{l}3.20 \pm 1.01 \\
\text { (A) }\end{array}$ & $5.232 *$ \\
\hline suit-like & $3.33 \pm 0.93$ & $3.26 \pm 1.15$ & $3.29 \pm 1.08$ & 0.053 \\
\hline
\end{tabular}

${ }^{*} p<.05,{ }^{* *} p<.01,{ }^{* * *} p<.001$

A, B : categorization of the groups for the significant differences between groups 
mature, casual, simple, cute, and suit-like.

The fashion pursuing type group was shown to prefer luxurious, fancy, fashionable, and casuals while the practical function pursuing type group was shown to prefer mature, simple and suit-like images(Table 9).

3) Comparison between the images of clothing products applied with digital fashion systems and preferred brand images

The images of preferred brands and the images of clothing products applied with digital fashion systems by each lifestyle group were compared and analyzed with a view to identifying the clothes images currently pursued as factors for planning of clothing products applied with digital fashion systems. This is an analysis based on the expectation that if the factor respondents' preferred brand images coincide with the images of clothing products applied with digital fashion systems, the group's demand level will rise. In addition, with regard to images' coincidence, cases where score differences exceeding 0.5 by vocabulary were regarded as cases of large image differences(Fig. 6).

The sensation information pursuing type group was shown to have coinciding images of preferred brands and clothing products applied with digital fashion systems in more factors compared to other group. This group's images of clothing products applied with digital fashion systems were shown to be more plain, masculine, and suit-like compared to the images of preferred brands indicating that these factors should be considered in product planning(Fig. 7).

The fashion pursuing type group shown to have less sensitive, more moderate, plainer, and cuter images for clothing products applied with digital fashion systems compared to preferred brand images. The fashion pursuing type group was shown to have large image differences compared to the sensation information pursuing type group indicating that when products are planned for the fashion pursuing type group, the products should be planned to be more sensitive to fashion and more individual(Fig. 8).

The practical function pursuing type group was shown to have less mature, more casual, masculine, cute, and unique images for clothing products applied with digital fashion systems compared to preferred brand images indicating that these factors should be considered in product planning.

In general, in the comparison and analysis of the images of cloth-

Table 9. Assessment of preferred brand image factors according to lifestyles

\begin{tabular}{|c|c|c|c|c|}
\hline \multirow{2}{*}{ Item } & Sensation information pursuing type & Fashion pursuing type & Practical function pursuing type & \multirow{2}{*}{ F-value } \\
\hline & Mean \pm SD & Mean \pm SD & Mean \pm SD & \\
\hline luxurious & $\begin{array}{c}3.91 \pm 1.19 \\
\text { (A) }\end{array}$ & $\begin{array}{c}4.38 \pm 0.69 \\
\text { (A) }\end{array}$ & $\begin{array}{c}4.23 \pm 1.03 \\
\text { (B) }\end{array}$ & $1.978^{*}$ \\
\hline fancy & $\begin{array}{c}2.96 \pm 1.33 \\
\text { (A) }\end{array}$ & $\begin{array}{l}3.19 \pm 1.20 \\
\text { (B) }\end{array}$ & $\begin{array}{c}2.98 \pm 1.13 \\
\text { (A) }\end{array}$ & $3.349 *$ \\
\hline feminine & $3.74 \pm 1.00$ & $3.88 \pm 1.21$ & $4.07 \pm 0.97$ & 1.055 \\
\hline fashionable & $\begin{array}{c}3.48 \pm 1.21 \\
\text { (A) }\end{array}$ & $\begin{array}{c}3.92 \pm 1.29 \\
\text { (A) }\end{array}$ & $\begin{array}{l}2.95 \pm 1.41 \\
\text { (B) }\end{array}$ & $4.636^{*}$ \\
\hline mature & $\begin{array}{c}3.23 \pm 1.04 \\
(\mathrm{AB})\end{array}$ & $\begin{array}{c}3.54 \pm 0.94 \\
\text { (A) }\end{array}$ & $\begin{array}{c}3.80 \pm 1.02 \\
\text { (A) }\end{array}$ & $3.349 *$ \\
\hline moderate & $3.28 \pm 1.31$ & $3.16 \pm 1.10$ & $3.30 \pm 1.25$ & 0.294 \\
\hline casual & $\begin{array}{c}3.30 \pm 1.22 \\
(\mathrm{AB})\end{array}$ & $\begin{array}{c}3.69 \pm 1.28 \\
\text { (B) }\end{array}$ & $\begin{array}{c}2.89 \pm 1.35 \\
\text { (A) }\end{array}$ & $3.299 *$ \\
\hline plain & $2.09 \pm 1.19$ & $1.62 \pm 0.69$ & $3.10 \pm 1.03$ & 1.978 \\
\hline simple & $\begin{array}{c}3.02 \pm 1.13 \\
\text { (A) }\end{array}$ & $\begin{array}{l}2.81 \pm 1.21 \\
\text { (B) }\end{array}$ & $\begin{array}{c}3.53 \pm 1.33 \\
\text { (A) }\end{array}$ & $3.349^{*}$ \\
\hline masculine & $2.26 \pm 1.00$ & $2.12 \pm 1.21$ & $1.93 \pm 0.97$ & 1.055 \\
\hline classic & $3.49 \pm 1.16$ & $3.00 \pm 1.41$ & $3.61 \pm 1.08$ & 2.252 \\
\hline cute & $\begin{array}{c}2.77 \pm 1.04 \\
\text { (B) }\end{array}$ & $\begin{array}{c}2.12 \pm 1.21 \\
\text { (B) }\end{array}$ & $\begin{array}{c}1.93 \pm 0.97 \\
\text { (A) }\end{array}$ & $3.349^{*}$ \\
\hline unique & $2.72 \pm 1.31$ & $2.70 \pm 1.25$ & $2.50 \pm 1.10$ & 0.294 \\
\hline suit-like & $\begin{array}{c}2.70 \pm 1.22 \\
\text { (A) }\end{array}$ & $\begin{array}{c}2.31 \pm 1.28 \\
(\mathrm{AB})\end{array}$ & $\begin{array}{c}3.09 \pm 1.32 \\
\text { (B) }\end{array}$ & $3.144^{*}$ \\
\hline
\end{tabular}

A, B : categorization of the groups for the significant differences between groups 


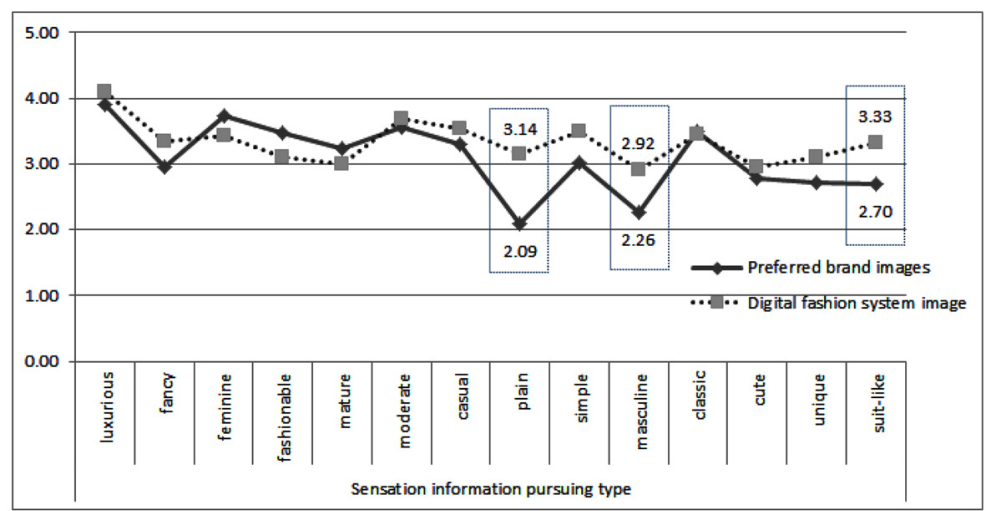

Fig. 6. Comparison and analysis of the sensation information pursuing type group's images of clothing products applied with digital fashion systems and the group's images of preferred brands.

ing products applied with digital fashion systems and the images of preferred brands, the number of items that showed differences exceeding 0.5 per item was the smallest at 3 in the sensation information pursuing type group indicating that this group is the market that is easiest to enter at the beginning as this group has the high coincidence between the images of clothing products applied with digital fashion systems and the images of preferred brands.

\subsection{Analysis of basic factors for planning of clothing products applied with digital fashion systems}

1) Analysis of preferred types of clothing products applied with digital fashion systems by lifestyle

Preferred types of clothing products applied with digital fashion systems were analyzed with a view to deriving clothing types with the highest marketability. The sensation information pursuing type group preferred casual inner-wear, casual bottoms, and suit outerwear as the most suitable clothing types while the fashion pursuing type group preferred suit outer-wear as the most suitable clothing type. The practical function pursuing type group was shown to prefer casual inner-wear the most followed by casual bottoms and casual outer-wear in order of precedence indicating that this group assesses casual wear is more suitable for the application of digital fashion system compared to suits(Table 10).

According to the results of integrated analysis of the groups, the clothing type that was expected to be preferred most for the application of digital fashion system was casual inner-wear followed by suit outer-wear, casual outer-wear, and casual bottoms in order of precedence(Fig. 9).

2) Analysis of factors to be considered for clothing products applied with digital fashion systems according to lifestyles

Items considered when MTM based clothing products applied with digital fashion systems were divided into six items; materials, designs, textile design, color, and silhouette and multiple responses

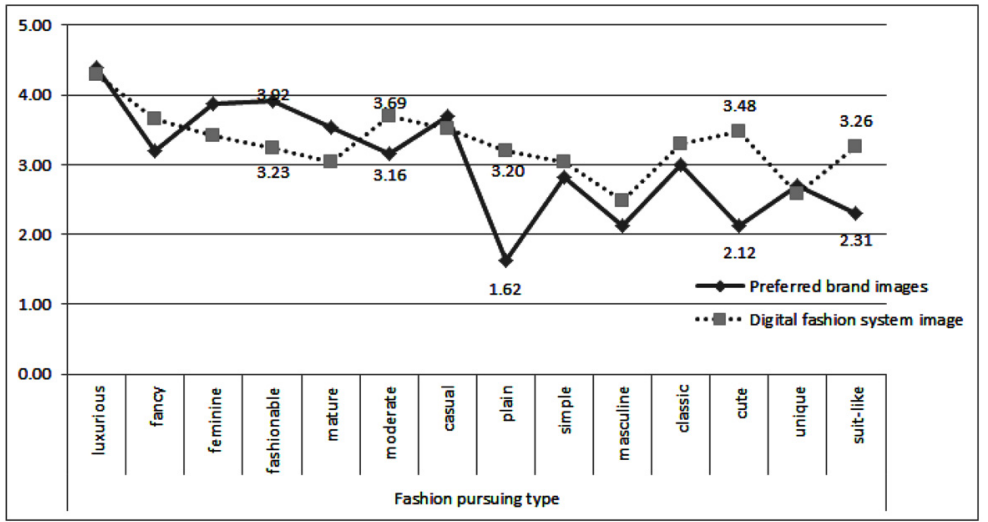

Fig. 7. Comparison and analysis of the fashion pursuing type group's images of clothing products applied with digital fashion systems and the group's images of preferred brands. 


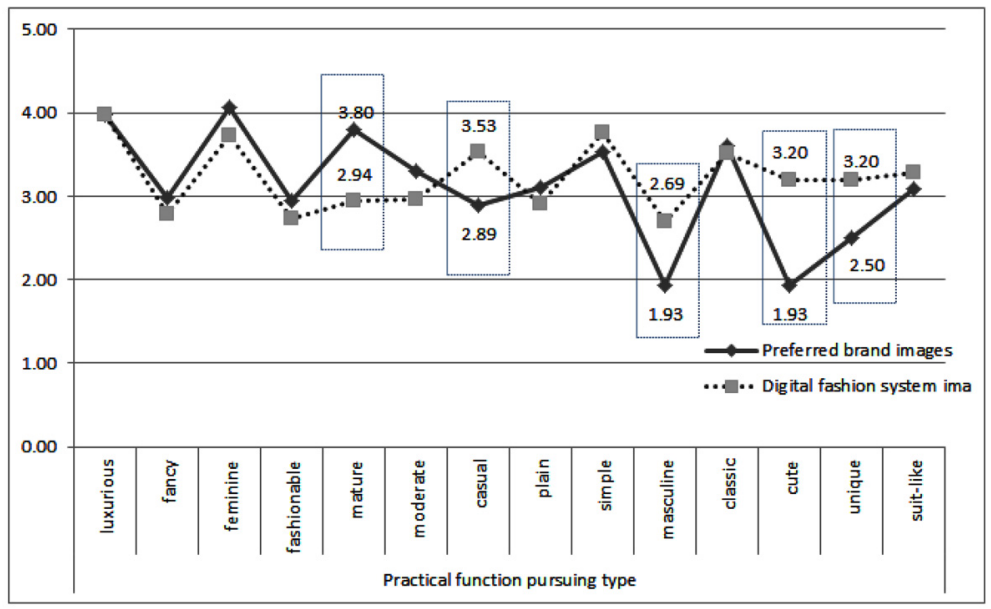

Fig. 8. Comparison and analysis of the practical function pursuing type group's images of clothing products applied with digital fashion systems and the group's images of preferred brands.

Table 10. Clothes preferred for the application of digital fashion systems according to lifestyles

\begin{tabular}{lcccc}
\hline \multirow{2}{*}{ Item } & Sensation information pursuing type & Fashion pursuing type & Practical function pursuing type & Total \\
\cline { 2 - 5 } & $\mathrm{N}(\%)$ & $\mathrm{N}(\%)$ & $\mathrm{N}(\%)$ & $\mathrm{N}(\%)$ \\
\hline Casual inner-wear & $23(18)$ & $16(17)$ & $29(21)$ & $69(19)$ \\
Suits inner-wear & $18(14)$ & $14(15)$ & $21(15)$ & $53(15)$ \\
Casual bottom & $23(18)$ & $12(12)$ & $24(17)$ & $59(16)$ \\
Suits bottom & $19(15)$ & $18(19)$ & $20(14)$ & $57(16)$ \\
Suits outer-wear & $23(18)$ & $22(23)$ & $23(16)$ & $68(19)$ \\
Casual outer-wear & $21(17)$ & $14(14)$ & $24(17)$ & $59(16)$ \\
\hline \multicolumn{1}{c}{ Total } & 127 & 96 & 141 & 365 \\
\hline
\end{tabular}

about factors that are considered important in buying clothes were obtained and according to the results, overall silhouette was shown to be given first priority followed by material, design, color, and textile design in order of precedence indicating that silhouette is a major factor that must be reflected when clothing is planned.

In addition, although assessment of factors that must be considered first when customized clothing products applied with digital fashion systems are bought showed no significant difference among the groups, the sensation information pursuing type group indicated that detailed selections should be made for silhouette, material, and color and the fashion pursuing type group indicated that design and color should be divided into detailed stages. Finally, the practical function pursuing type group indicated that among detailed selections, material was the most important followed by color. This indicated that because of the nature of customized clothing product applied with MTM based digital fashion systems for which items presented on the monitor should be selected(Table 11), material and color that cannot be easily assessed based on images on the monitor should be considered. Therefore, color and material

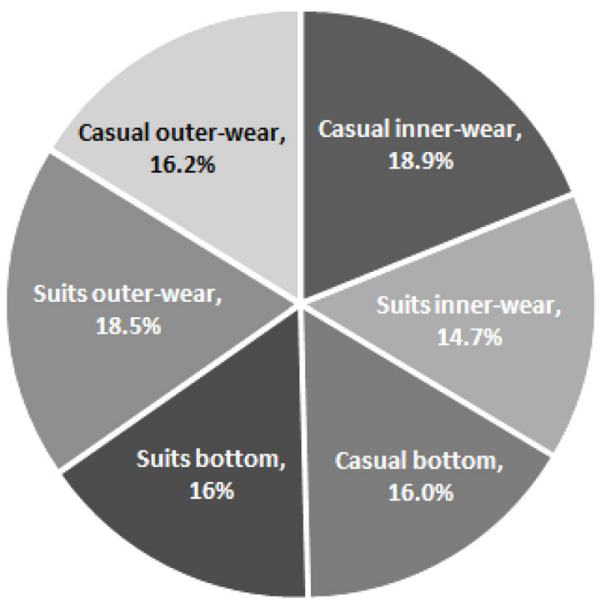

Fig. 9. The results of analysis of clothing types suitable for the application of digital fashion systems.

can be presented as planning factors for which selection items should be subdivided and visualization of the details should be applied to the selection of them on the monitor through the assessment of preferred brands by group and comprehensive assess- 


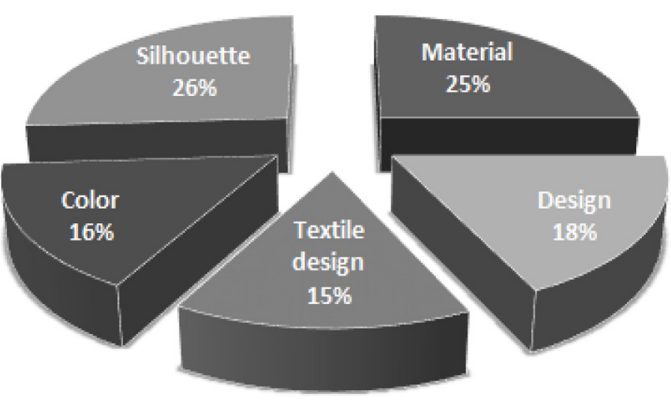

Fig. 10. Factors to be considered for customized clothing applied with digital fashion systems.

ment(Fig. 10).

\section{Conclusion}

The results of analysis of consumer demand levels for customized clothing products applied with digital fashion systems and product planning factors according to lifestyles are as follows.

1) Lifestyles were divided into three groups; fashion pursuing type, sensation information pursuing type, and practical function pursuing type groups.

2) Clothing products applied with digital fashion systems were identified to have fancy, fashionable, and unique images through analysis. By lifestyle, the fashion pursuing type group was shown to assess the products as having fancy, fashionable, and unique images while the practical function pursuing type group was identified to have more moderate images compared to other groups. In addition, demand for casual type clothes was derived in general so that a direction of product planning can be presented and in particular, the factors, silhouettes and colors were identified as the most important factors. These results seem to reflect diverse differences in the system in which consumers indirectly wear and select clothes utilizing monitors due to the characteristics of the digital fashion system presented in the present study. Therefore, silhouettes and colors should be presented in detail through stepwise system level designs when the clothing applied with the system is planned.

3) The fashion pursuing type group is a group with a strong tendency toward early adopters that tends to prefer individual clothing and follow contemporary fashions. This group was shown to have high awareness of clothing products applied with digital fashion systems but lower acceptance compared to other groups. This group that prefers expensive stylish character trend casuals such as Andew, Kai-Aakmann, and Chris Christy was shown to have plainer, cuter, unique, and more suit-like images for preferred brands compared to clothing products applied with digital fashion systems.

The fashion pursuing type group was shown to consider the factors fashion and colors the most when they buy clothes and have highest demand for suit outer-wear among the types of clothing applied with digital fashion systems. It was identified that this group required detailed selection stages for silhouettes and colors if the system would be applied. Although this group did not show big differences in image analysis, given the integrated results, early introduction of the market of clothing products applied with digital fashion systems for this group is considered difficult.

4) The sensation information pursuing type group was shown to have the highest necessity and acceptance of clothing products applied with digital fashion systems indicating the highest potential for initial markets. This group was shown to pursue classic, luxurious and elegant brands prefer sensual value casual lines such as EmPolham and Mind Bridge. This group was identified as a group with the least difference between the images of preferred brands and the images clothing products applied with digital fashion systems and thus as a group with the highest demand for clothing products applied with digital fashion systems. Among the types of clothing products applied with digital fashion systems, this group preferred casual bottoms and casual outer-wear the most. Therefore, when the system is introduced, stepwise planning factors should be introduced to satisfy this group's demand for introduction of details stages for silhouettes, materials, and colors.

Table 11. Multiple response analysis major factors considered according to lifestyles

\begin{tabular}{lcccc}
\hline \multirow{2}{*}{ Item } & Sensation information pursuing type & Fashion pursuing type & Practical function pursuing type & \multirow{2}{*}{ Total } \\
\cline { 2 - 4 } & $\mathrm{N}(\%)$ & $\mathrm{N}(\%)$ & $\mathrm{N}(\%)$ & \\
\hline Material & $48(22)$ & $32(16)$ & $82(28)$ & $162(23)$ \\
Design & $44(20)$ & $52(26)$ & $42(14)$ & $138(19)$ \\
Textile design & $30(14)$ & $28(14)$ & $32(11)$ & $90(13)$ \\
Color & $38(17)$ & $50(25)$ & $74(25)$ & $162(23)$ \\
Silhouette & $62(28)$ & $38(19)$ & $64(22)$ & $164(23)$ \\
\hline \multicolumn{1}{c}{ Total } & $222(100)$ & $200(100)$ & $294(100)$ & $716(100)$ \\
\hline \multicolumn{1}{c}{} \\
\cline { 2 - 4 }
\end{tabular}


5) The practical function pursuing type group showed the lowest awareness of clothing products applied with digital fashion systems among the three groups but showed the highest score for acceptance along with the sensation information pursuing type group. This group showed a tendency to prefer easy casuals such as TBJ and Giordano. This group was identified to regard practical aspects the most important when buying clothing considered those factors such as easiness of management, sewn states, functionality, and price adequacy.

The practical function pursuing type group was shown to have fancier, more feminine, and mature images for clothing products applied with digital fashion systems compared to preferred brand images and showed differences in the largest number of items next to the fashion pursuing type group among the three groups indicating that initial entry into the market should be difficult. Based on the results of analysis of the types of clothing products applied with digital fashion systems, this group was shown to have the highest demand for casual inner-wear followed by casual outer-wear and casual bottoms in order of precedence. This group required detailed selection systems for the factors; materials and colors when they would buy the clothing products indicating that these factors should be reflected during planning.

The present study is meaningful in that it provided basic data for product planning through digital fashion systems by analyzing the awareness, preference, necessity, and planning factors of digital fashion systems through the analysis of lifestyle types. However, although the present study was conducted centering on those in their 20,30s, studies should be conducted later through surveys with consumers in a wide range of ages. In addition, follow-up studies are required that would present detailed product planning proposals through research and surveys that classify factors for product planning in detail and approach to the factors.

\section{References}

Choi, E. D. (2002). A study on the fashion planing based on domestic consumer's lifestyle and preference of current fashion trends: focused on the women's wear brands $T$ and $M$. Unpublished master's thesis, Yonsei University, Seoul.

Chun, J. S., \& Lim, H. S. (2003). A study on the use of MTM CAD program for mass customization of men's suit. The Research Journal of the Costume Culture, 11(5), 647-656.

Eun, M. J. (2004). A study on a design precess model for masscustomized design product: On the basis of internet shopping. Unpublished master's thesis, Yonsei University, Seoul.

Eun, M. J., \& Lee, J. H. (2006). A study on a design precess model for mass-customized fashion product(Part I): On the basis of internet shopping. Journal of the Korean Society of Clothing and Textiles, 30(2), 187-197.

Jang, S. E., \& Chang, J. H. (2008). A study on a men's dress shirt pattern by somatotype for mass customization system. Journal of the Korea Society of Clothing and Textiles, 32(2), 294-306.

Korea Federation of Textile Industries. (2008). 산업 IT 융합포럼 섬유분과위원회 종합활성화 방안 보고서 [Report of the overall activation for IT convergence in Textile Industries, IT Convergence Forum Textile sub-committee]. Seoul: Author.

Lee, J. W. (2002). A study on the fashion design process model for mass customized printed clothing. Unpublished master's thesis, Yonsei University, Seoul.

Lee, J. R. (2004). A study on smart home of resident importance : chiefly for lifestyle and residential living mode. Unpublished master's thesis, Yonsei University, Seoul.

Lim, H. S., \& Istook, C. L. (2011). A study of the made-tomeasure(MTM) CAD system for mass customization. Proceedings of the Korean Society of Clothing and Textiles, Spring Conference, Korea, pp. 101-102.

Park, J. A. (2003). A study of the fashion design process model for mass customized clothing. Unpublished master's thesis, Yonsei University, Seoul.

Park, S. M. (2002). A study on fashion planning based on a casual trend in men's business wear as a result of the consumer's preference and lifestyle. Unpublished master's thesis, Yonsei University, Seoul.

Samsung Economic Research Institute. (2003). CEO Information: Mass Customization 의 대두와 기업의 대응 [Rasing of the Mass Customization and Response of Corporation]. Seoul: Author.

(Received 22 January 2015; 1st Revised 4 February 2015; 2nd Revised 12 February 2015; Accepted 23 February 2015)

(C) 2015 (by) the authors. This article is an open access article distributed under the terms and conditions of the Creative Commons Attribution license (http://creativecommons.org/licenses/by/3.0/), which permits unrestricted use, distribution, and reproduction in any medium, provided the original work is properly cited. 